\title{
Hydrothermal Carbonization (HTC) of Seaweed (Macroalgae) for Producing Hydrochar
}

\author{
Neel Patel ${ }^{1}$, Bishnu Acharya ${ }^{2, *}$ and Prabir Basu ${ }^{1}$ \\ 1 Department of Mechanical Engineering, Dalhousie University, Halifax, NS B3H4R2, Canada; \\ patel.neel@dal.ca (N.P.); prabir.basu@dal.ca (P.B.) \\ 2 Department of Chemical and Biological Engineering, University of Saskatchewan, \\ Saskatoon, SK S7N5A9, Canada \\ * Correspondence: bsp874@usask.ca
}

check for updates

Citation: Patel, N.; Acharya, B.; Basu, P. Hydrothermal Carbonization (HTC) of Seaweed (Macroalgae) for Producing Hydrochar. Energies 2021, 14, 1805. https://doi.org/10.3390/ en14071805

\section{Academic Editor:}

Alberto-Jesus Perea-Moreno

Received: 12 February 2021

Accepted: 21 March 2021

Published: 24 March 2021

Publisher's Note: MDPI stays neutral with regard to jurisdictional claims in published maps and institutional affiliations.

Copyright: (c) 2021 by the authors. Licensee MDPI, Basel, Switzerland. This article is an open access article distributed under the terms and conditions of the Creative Commons Attribution (CC BY) license (https:// creativecommons.org/licenses/by/ $4.0 /)$.

\begin{abstract}
Waste seaweed that is collected at coastal regions of maritime provinces in Canada is creating ecological problems as it promotes an anoxic event, which produces nearly zero dissolved oxygen in water along with hydrogen sulfide emission. The work done in this study attempts to address this issue by producing a coal-like solid hydrochar and nutritious liquid slurry (processed water) by employing a rather recent thermo-chemical process called hydrothermal carbonization (HTC) on the seaweed. The HTC was carried out in a batch reactor system for three different reaction temperatures, $180{ }^{\circ} \mathrm{C}, 200^{\circ} \mathrm{C}, 220^{\circ} \mathrm{C}$, and three different reaction times, 30, 60, and $120 \mathrm{~min}$. Each of the produced hydrochars was characterized by different analytical methods. The effects of the process conditions on the yield and the properties of the hydrochar and process water were examined. The hydrochar produced at $220{ }^{\circ} \mathrm{C}$ and $120 \mathrm{~min}$ showed the highest carbon content $(48.5 \%)$ and heating value $(18.93 \mathrm{MJ} / \mathrm{kg})$. The energy density and carbon to nitrogen $(\mathrm{C} / \mathrm{N})$ ratio in the hydrochar increased significantly as compared to raw seaweed. Moreover, HTC reduced the ash yield and volatile compounds of the seaweed. Thus, hydrochar can be used as a fuel for direct combustion, in soil remediation, or in carbon sequestration applications.
\end{abstract}

Keywords: hydrothermal carbonization; seaweed; hydrochar; wet biomass; bio-coal; biomass conversion

\section{Introduction}

Biomass is a collective term to describe organic materials from plants or animals, and their derived wastes [1-3]. Biomass can be broadly classified into three groups: terrestrial biomass (forest, grasses, energy crops, etc.), aquatic biomass (algae, marine plants, etc.), and waste biomass (municipal solid waste, agricultural waste, forestry residues, etc.). The biobased economy, which uses eco-efficient bioprocesses for transforming biomass into more valuable biofuels, is one of the key strategic challenges of the 21st century [4,5]. Utilization of biomass for the production of biofuels reduces greenhouse gas emissions, improves air quality, and helps to achieve energy independence as well as energy security [6,7]. A number of processes have been studied for biomass conversion, including thermochemical (torrefaction, hydrothermal carbonization, pyrolysis, liquefaction, gasification, combustion) and biological (fermentation, anaerobic digestion) processes. The selection of the conversion process depends on the type of biomass and the final application. Hydrothermal carbonization is being developed for the conversion of wet biomass to biofuels and for the recovery of nutrients such as phosphorus and nitrogen. Recent reviews by Khan et al. [8], Shen et al. [9], Wang et al. [1], Sharma et al. [10], Heidari et al. [11] highlight the reaction mechanism and the development of the HTC process. In brief, the utilization of hot compressed water allows complex reaction cascades to take place, including decomposition and depolymerization of biomass feedstock, which results in carbon-rich and energy-dense hydrochar and nutritious processed water [11-16]. The water during HTC conditions is 
characterized by lower ionic product, higher dielectric constant, and higher heat capacity, which can significantly affect the yield and properties of HTC products [17]. A wide variety of literature shows that the reaction temperature and the reaction time affect the distribution and properties of the resultant products in the HTC process [18-21]. The higher carbon content, heating value, and energy density and the lower inorganic matter, improved hydrophobicity, and modified microcrystalline structure and morphology as compared to raw biomass could lead to the broad application of hydrochar in various fields, including the energy, catalyst, adsorbent, and medical fields $[8,22,23]$. The reduced inorganic content and improved fuel properties of hydrochar could mitigate the problems associated with direct combustion of biomass, such as slagging, scaling, and fouling in boilers $[13,14,24,25]$. In summary, elimination of the energy-intensive drying process, relatively low temperature and shorter residence time, and removal of inorganic impurities are significant advantages of the HTC process over other thermochemical processes for the conversion of wet biomass. Most of the lab-scale studies have been carried in a batch-type reactor. The reactors that have been used involve Parr reactors, autoclaves, and stainless-steel reactors immersed in oil baths $[26,27]$. At the industrial scale, HTC technology was first launched by AVA$\mathrm{CO}_{2}$ in 2010 in Germany. The plant has an overall capacity of 14,400 L and an annual capacity to process 8400 tonnes of biomass [28]. The SunCoal plant known as CarbonREN technology is another technology developed and tested for wood, leaves, and grass. The bio-coal produced could be used as a source of heat and power. Ingelia developed a hydrothermal carbonization plant with an annual biomass capacity of 1100 tons. The reactor for HTC is a vertical cylinder where preheated biomass is fed from the bottom, and the outlet for the mixture of hydrochar and water is also present at the bottom [29]. Heidari et al. [11] summarized the challenges in the development of HTC, which include limited knowledge of the reaction kinetics of the HTC process, finding applications for process water along with hydrochar, and continuous feeding of biomass against high pressure. Ankita et al. [30,31] developed a semi-continuous HTC system to overcome the problem of feeding against pressure. More work is needed for the development of technology and application of the hydrochar and process water. Seaweed or macroalgae belong to the lower plant, meaning that they do not have roots, stems, and leaves [32]. In the natural environment, seaweeds live near the seabed and form stable and multilayered vegetation, capturing almost all available photons [32,33]. Approximately 10,000 species of seaweed exist in nature, and the distribution of seaweed primarily depends on the quality and quantity of the incidental solar radiation [34]. Seaweed accumulation is rapidly increasing near the town of Summerside in Prince Edward Island (PEI), Canada. It was reported that in the year 2014, a total of 4200 cubic meters of seaweed was removed from the city's shorelines, which proliferated, and it was reported that 70 cubic meters of waste seaweed were collected within a period of less than a month in the year 2017 [35]. The provincial government has identified that it is non-edible waste seaweed, and they have been trying to utilize it as compost or fertilizer since the year 2011 [36]. However, there have been complaints regarding strong, unpleasant, and toxic smells near the farms that have been using these seaweeds as fertilizers [37]. The Chief Administrative Officer (CAO) of Summerside also stated about this waste seaweed that "It is a bio-resource, and there is a potential we hope for energy production, biofuel, value-added products, nutraceuticals, other forms of fertilizers or chemicals" [38]. Developing a value-added solution to address the problems caused by overgrown seaweed can help to overcome the challenges related to its disposal. The value-added product could substitute petroleum-based fuels and/or materials and support the development of a bioeconomy [39].

In this study, hydrothermal carbonization (HTC) of the marine seaweed that is found near the shores of Prince Edward Island in Canada is investigated to understand the potential of the seaweed to produce a coal-like solid (hydrochar). The hydrochar is characterized for its physical, chemical, heating value, and mineral composition and the results are discussed in the paper. 


\section{Materials and Methods}

\subsection{Experimental Material}

The waste seaweed (Figure 1a) growing on the surface of seawater near Summerside, Prince Edward Island, Canada was considered for this study. Fresh seaweed was manually harvested. The collected seaweed was dehydrated in a commercially available dehydrator at $70{ }^{\circ} \mathrm{C}$ for $3 \mathrm{~h}$ and was ground in a commercially available grinder. As the size of the particles was not of much importance for this research, particle size was not measured. Finally, the ground seaweed (Figure 1b) was stored in a sealed plastic bag and kept inside a commercial refrigerator below $5{ }^{\circ} \mathrm{C}$ until HTC treatment. Three sets of experiments were performed. For the first two sets of experiments, $15 \mathrm{~g}$ of seaweed and $135 \mathrm{~mL}$ of deionized water were added into the reactor container. For the third set of experiments, $20 \mathrm{~g}$ of seaweed and $180 \mathrm{~mL}$ of deionized water were added into the reactor chamber. Thus, a 1:9 $(w / w)$ solid to water ratio was maintained for all the experiments. In all sets of experiments, the mixture was manually stirred to ensure total wetting of the seaweed before closing the lid of the reactor container.

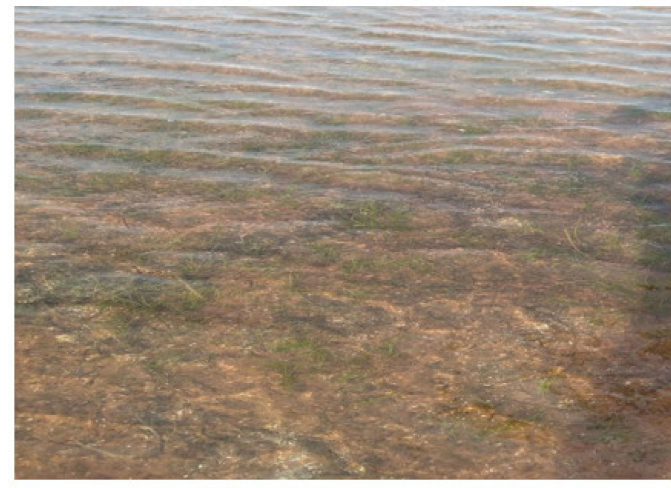

(a)

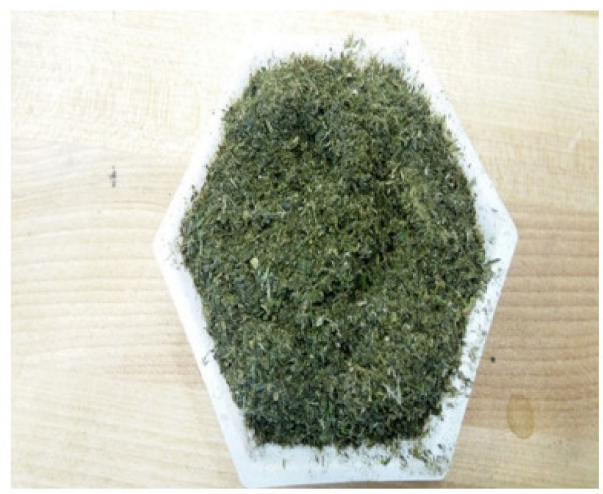

(b)

Figure 1. Fresh seaweed on sea surface (a) and ground seaweed (b).

\subsection{Experimental Methodology (HTC of Seaweed)}

The HTC experiments were carried out in a PARR 4571 High-Temperature/HighPressure batch reactor equipped with a magnetic stirrer and temperature controller. The seaweed and water at the ratio of 1:9 $(w / w)$ were placed inside the reactor. Before heating the reactor, the reactor was purged with nitrogen to maintain an inert environment. The heater was then turned on, and the desired temperature was set using the temperature controller. The temperature inside the reactor was continuously monitored and controlled by the PID controller system attached to the batch reactor. It took around $55 \mathrm{~min}, 70 \mathrm{~min}$, and $80 \mathrm{~min}$ for the heater to reach the setpoint temperature of $180{ }^{\circ} \mathrm{C}, 200^{\circ} \mathrm{C}$, and $220^{\circ} \mathrm{C}$ inside the reactor. The reaction time of the HTC process was calculated once the temperature inside the reactor reached the set values for the experiment. The reactor pressure was only monitored from the pressure gauge attached to the movable head, and it was not controlled in order to keep the pressure inside the reactor autogenic with the vapor pressure of the water at the corresponding temperature. The pressure indicated by the pressure gauge, mounted on the movable head of the reactor, was $1.72 \mathrm{MPa}, 2.56 \mathrm{MPa}$, and $3.45 \mathrm{MPa}$ for the reaction temperature $180{ }^{\circ} \mathrm{C}, 200{ }^{\circ} \mathrm{C}$, and $220^{\circ} \mathrm{C}$, respectively. The experiments were performed at three different reaction temperatures $\left(180{ }^{\circ} \mathrm{C}, 200^{\circ} \mathrm{C}, 220^{\circ} \mathrm{C}\right)$ and three different reaction times ( $30 \mathrm{~min}, 60 \mathrm{~min}, 120 \mathrm{~min}$ ) to study the effect on the properties of hydrochar and processed water. After the desired reaction time, the heater was turned off and the valve for the external cooling loop connected with a domestic cold-water line was opened to cool the reactor quickly for preventing further reactions. Although it took around $3 \mathrm{~h}$ for the temperature inside the reactor to reach room temperature, it only took 2-4 $\mathrm{min}$ for the temperature inside the reactor to drop below $150{ }^{\circ} \mathrm{C}$. This is vital because 
neither the chemical nor the organic decomposition of biomass is seen below $150{ }^{\circ} \mathrm{C}$ [40]. Once the temperature inside the reactor reached room temperature, the gas valve was opened to release the gaseous products. Then, the compression bolts were unscrewed, and the movable head was removed. The two-phase mixture of solid and liquid products of the HTC process, also called the wet slurry, was then transferred to a glass beaker, and the weight of the slurry was noted.

\subsubsection{Product Separation}

The principle of gravity filtration was applied to separate solid and liquid products of HTC from the two-phase mixture, i.e., the wet slurry. A commercially available paper coffee filter was used for this process. The liquid product, i.e., the processed water, can be seen in Figure 2a, and the solid product, i.e., the wet hydrochar, after the filtration, is shown in Figure 2b. The weight of the wet hydrochar was recorded, after which the wet hydrochar was dried in an oven. All the hydrochar samples were dried overnight at $105{ }^{\circ} \mathrm{C}$. The dried sample was weighted and stored in the refrigerator for further analyses. Furthermore, the volume of the processed water was noted for all samples, and each liquid sample was then transferred to a falcon tube for storing the sample in the refrigerator before further analyses.

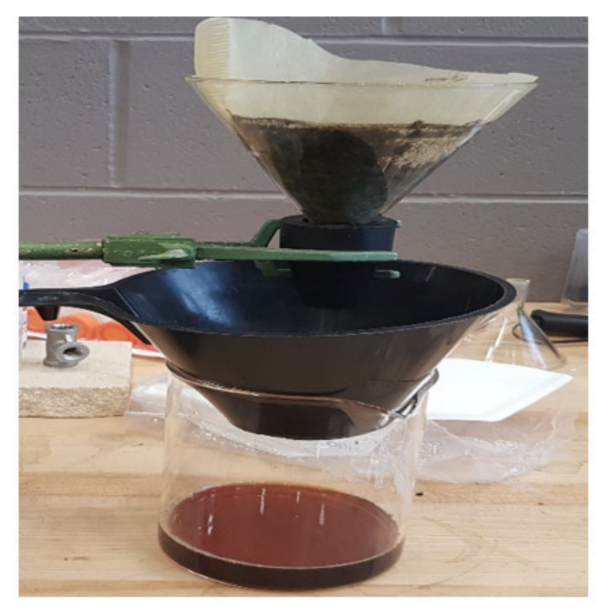

(a)

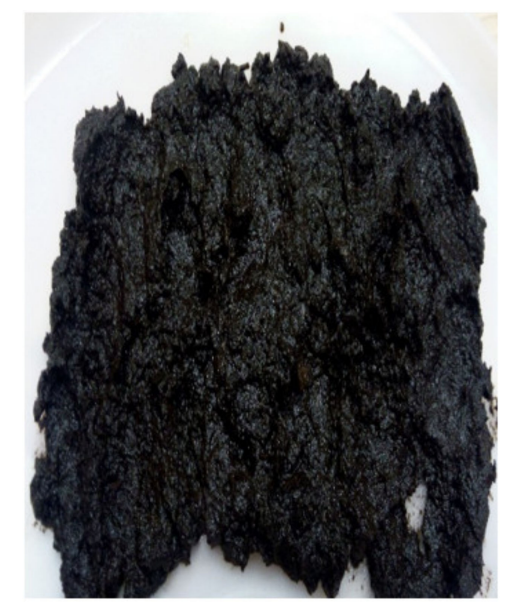

(b)

Figure 2. Gravity filtration of HTC products. (a) process water and (b) wet hydrochar.

\subsubsection{Product Analyses.}

The hydrochar samples were analyzed for the moisture content, ash content, volatile matter, and fixed carbon. Hydrochar proximate analysis was conducted using ASTM E1755 for ash analysis and ASTM E872 for volatile matter. For the ash analysis, the crucible with a dry sample was placed in the muffle furnace, and the furnace was heated to $250{ }^{\circ} \mathrm{C}$ for an hour. It was then heated to $575^{\circ} \mathrm{C}$ for an hour, and finally, it was kept at $575{ }^{\circ} \mathrm{C}$ for two hours. After heating, the crucible was moved to the desiccator and the ash percentage is calculated as the ratio of biomass weight in the crucible after heating to initial weight of dry biomass. For the volatile matter in a hydro-char sample, the crucible with a dried sample was transferred to the muffle furnace, which was pre-heated to $950{ }^{\circ} \mathrm{C}$. The samples were kept in the furnace for 7 minutes. The ratio of weight loss during the heating to initial weight of biomass gives the volatile matter. All the analyses were performed three times, and the mean value of the result is reported. The following equations were used to determine the solid yield Equation (1) liquid yield Equation (2), gas yield Equation (3) and the mass yield Equation (4) of the hydrochar.

$$
\text { Solid Yield }(\%)=\frac{\text { Mass of the solid after HTC }}{\text { Mass of the feedstock }} \times 100
$$




$$
\begin{gathered}
\text { Liquid Yield }(\%)=\frac{\text { Mass of the liquid after HTC }}{\text { Total mass of the feedstock }} \times 100 \\
\text { Gas Yield }(\%)=100-(\text { Solid Yield }+ \text { Liquid Yield }) \\
\text { Mass Yield }(\%)=\frac{\text { Mass of the dried solid after HTC }}{\text { Mass of the dried raw seaweed }} \times 100
\end{gathered}
$$

The ultimate analysis was performed to determine the carbon, hydrogen, nitrogen, sulfur, and oxygen content in the hydrochar. The ultimate analysis for the hydrochar samples was carried out using organic elemental analysis equipment (Flash 2000 CHNS-O). The higher heating values (HHV) for the hydrochar samples were calculated using the bomb calorimeter (Parr 6100 Calorimeter). Energy densification ratio (EDR) Equation (5) and the energy yield Equation (6) were calculated from the following expressions:

$$
\begin{aligned}
& \text { Energy Densification Ratio }(E D R)=\frac{\text { HHV of the product }}{\text { HHV of the raw seaweed }} \\
& \text { Energy Yield }(\%)=\text { Energy Densification Ratio } \times \text { Mass Yield }
\end{aligned}
$$

The mineral analysis of the hydrochar and processed water was carried out at the Prince Edward Island Analytical Laboratories, Charlottetown, PE, Canada. The chemical composition was obtained using atomic absorption spectrophotometry following the Association of Official Analytical Chemists (AOAC) 968.08 procedure. The effect of HTC conditions on the ash yield and the ash composition was studied. Ash yield Equation (7) and inorganic yield Equation (8) were calculated from the following expression:

$$
\begin{aligned}
\text { Ash Yield } & =\frac{\text { Ash content in the hydrochar }}{\text { Ash content in the raw seaweed }} \times \text { Mass Yield } \\
\text { Inorganic Yield } & =\frac{\text { Inorganic content in the hydrochar }}{\text { Inorganic content in the raw seaweed }} \times \text { Mass Yield }
\end{aligned}
$$

The $\mathrm{pH}$ of the process water was measured using a Vernier $\mathrm{pH}$ meter. First, $100 \mathrm{~mL}$ of sample was taken in a beaker, and the electrode was immersed in it. The $\mathrm{pH}$ was then observed in Logger pro 3 software (3, Beaverton, OR, USA).

\section{Results and Discussion}

\subsection{Effect of the HTC Process Conditions on the Product Yields}

Table 1 shows the product yield after HTC experiments at different reaction conditions. The gas yield data are calculated by the difference. The effect of temperature and reaction time on the product is discussed in following section.

Table 1. The solid, liquid, and gas yield from HTC process.

\begin{tabular}{cccccc}
\hline \multicolumn{2}{c}{ Process Parameters } & \multicolumn{4}{c}{ Product Yields } \\
\hline Temperature $\left({ }^{\circ} \mathbf{C}\right)$ & Time (min) & Solid Yield (\%) & Liquid Yield (\%) & Gas Yield (\%) & Mass Yield (\%) \\
\hline 180 & 30 & $40.2 \pm 1.33$ & $54 \pm 1.67$ & $5.8 \pm 0.33$ & $46.9 \pm 0.89$ \\
180 & 60 & $38.45 \pm 2.05$ & $55 \pm 1.62$ & $6.55 \pm 0.43$ & $45.65 \pm 0.36$ \\
180 & 120 & $35.55 \pm 1.38$ & $59 \pm 0.90$ & $5.45 \pm 0.47$ & $45.3 \pm 1.39$ \\
200 & 30 & $38 \pm 0.41$ & $56 \pm 1.66$ & $6 \pm 1.26$ & $45.95 \pm 2.09$ \\
200 & 60 & $33.65 \pm 2.73$ & $60 \pm 2.85$ & $5.58 \pm 0.12$ & $41.8 \pm 0.08$ \\
200 & 120 & $30.8 \pm 0.60$ & $64.5 \pm 1.49$ & $4.7 \pm 2.09$ & $39.7 \pm 0.52$ \\
220 & 30 & $28.75 \pm 2.62$ & $65 \pm 1.68$ & $6.25 \pm 0.93$ & $36.1 \pm 1.08$ \\
220 & 60 & $29.4 \pm 1.01$ & $65.50 \pm 2.84$ & $5.1 \pm 1.83$ & $34.65 \pm 1.65$ \\
220 & 120 & $25.6 \pm 0.77$ & $68.50 \pm 1.86$ & $5.9 \pm 1.08$ & $30.5 \pm 1.61$ \\
\hline
\end{tabular}




\subsubsection{Effect of Temperature on the Product Yield}

Figure 3 shows the effect of temperature on the product yields. From the figure, it is evident that the solid yield decreased by $2-5 \%$ as the reaction temperature increased from $180{ }^{\circ} \mathrm{C}$ to $200{ }^{\circ} \mathrm{C}$. It further dropped by $5-10 \%$ as the reaction temperature increased to $220^{\circ} \mathrm{C}$. On the other hand, the liquid yield continued to increase by $2-6 \%$ with the increase in the reaction temperature from $180{ }^{\circ} \mathrm{C}$ to $200{ }^{\circ} \mathrm{C}$, and by $4-9 \%$ when the reaction temperature was increased from $200{ }^{\circ} \mathrm{C}$ to $220^{\circ} \mathrm{C}$. Gas yield, however, remained nearly constant with the change in the reaction temperature. Like the solid yields, the mass yield of the hydrochar samples, as can be seen in Figure 4, reduced as the temperature was increased. At a given reaction time, the mass yield of the hydrochar reduced by $12-15 \%$ with an increase in the reaction temperature from $180^{\circ} \mathrm{C}$ to $220^{\circ} \mathrm{C}$.

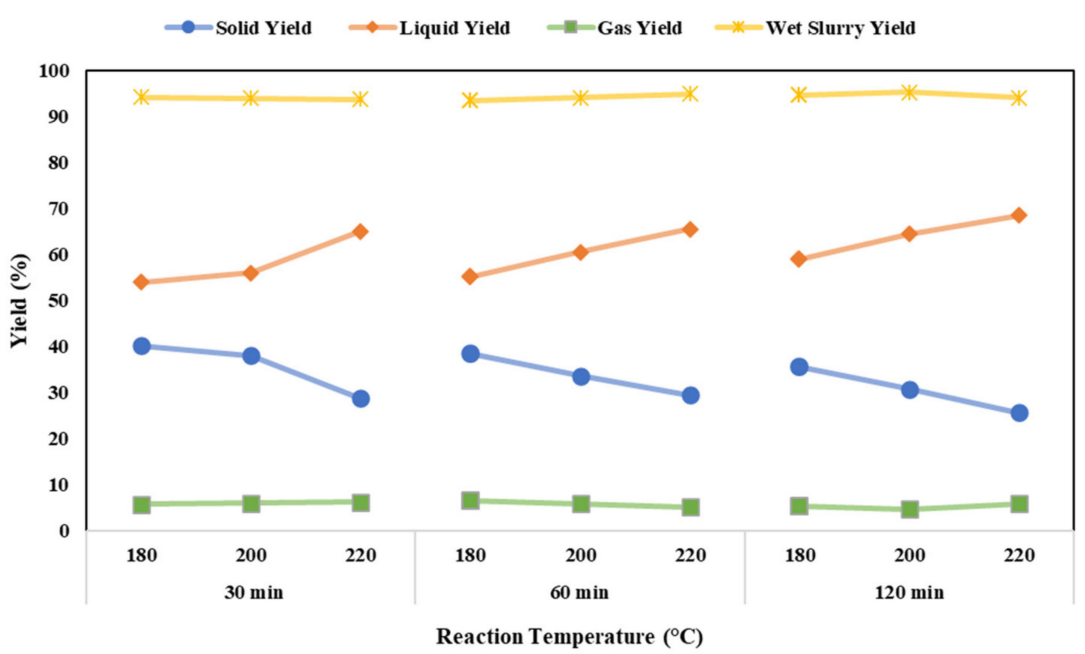

Figure 3. Effect of the reaction temperature on the product yields in HTC.

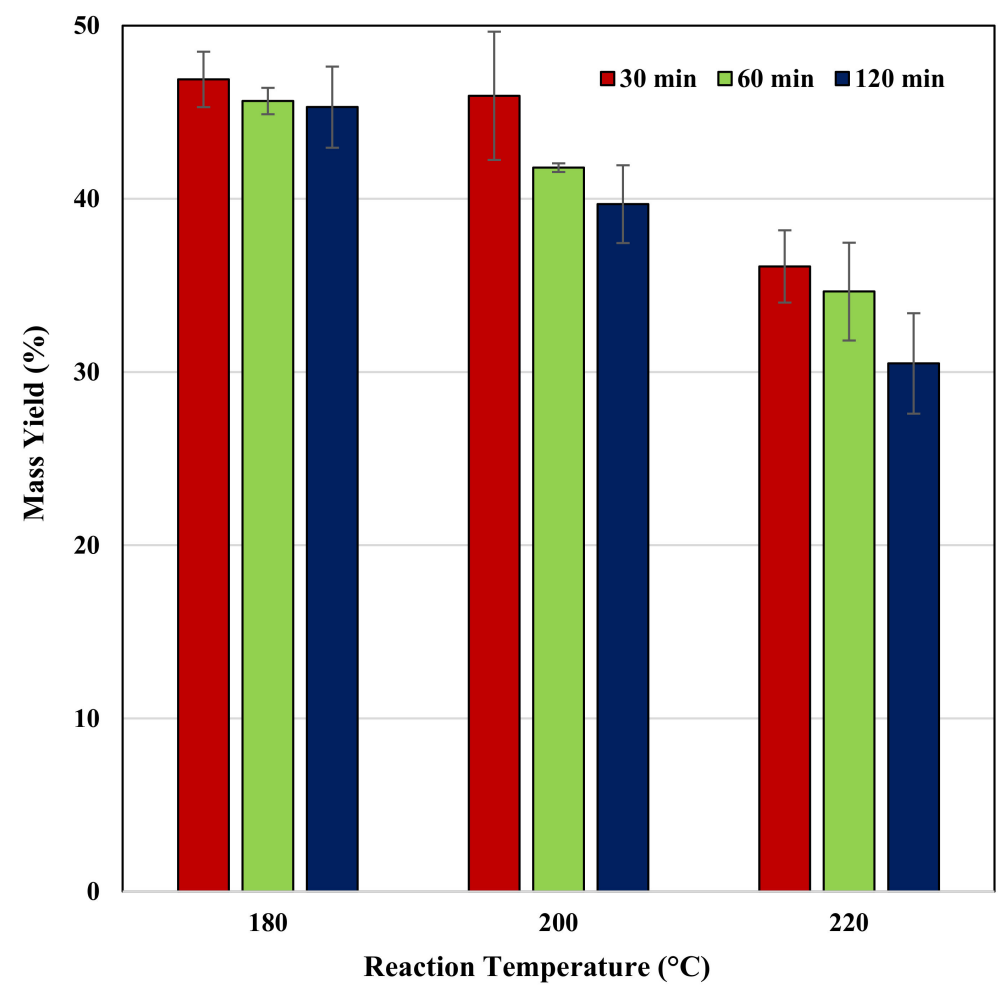

Figure 4. Effect of the reaction temperature on the mass yield of the hydrochar in HTC. 
These trends of the product yields for the change in the HTC process conditions are consistent with the findings in the literature [41]. The compressed water in HTC conditions allows for better penetration into porous biomass and thus results in lower activation energy $[8,21,42]$. The hemicellulose in the seaweed degrades first at the lowest temperature, which represents the mass loss within the temperature range of $180-200{ }^{\circ} \mathrm{C}$. As the temperature is increased from $200{ }^{\circ} \mathrm{C}$ to $220^{\circ} \mathrm{C}$, further hydrolysis of cellulose results in lower mass yield of the hydrochar $[8,43]$. Hence, it is reasonable to postulate that a higher process temperature in the HTC process triggers the decomposition of different biomass components, causing a lower solid yield and higher liquid yield.

\subsubsection{Effect of the Reaction Time on the Product Yields in HTC}

Figure 5 shows the trend of the product yield at different reaction times. With the increase in reaction time from $30 \mathrm{~min}$ to $120 \mathrm{~min}$, the solid yield decreases for a given temperature.

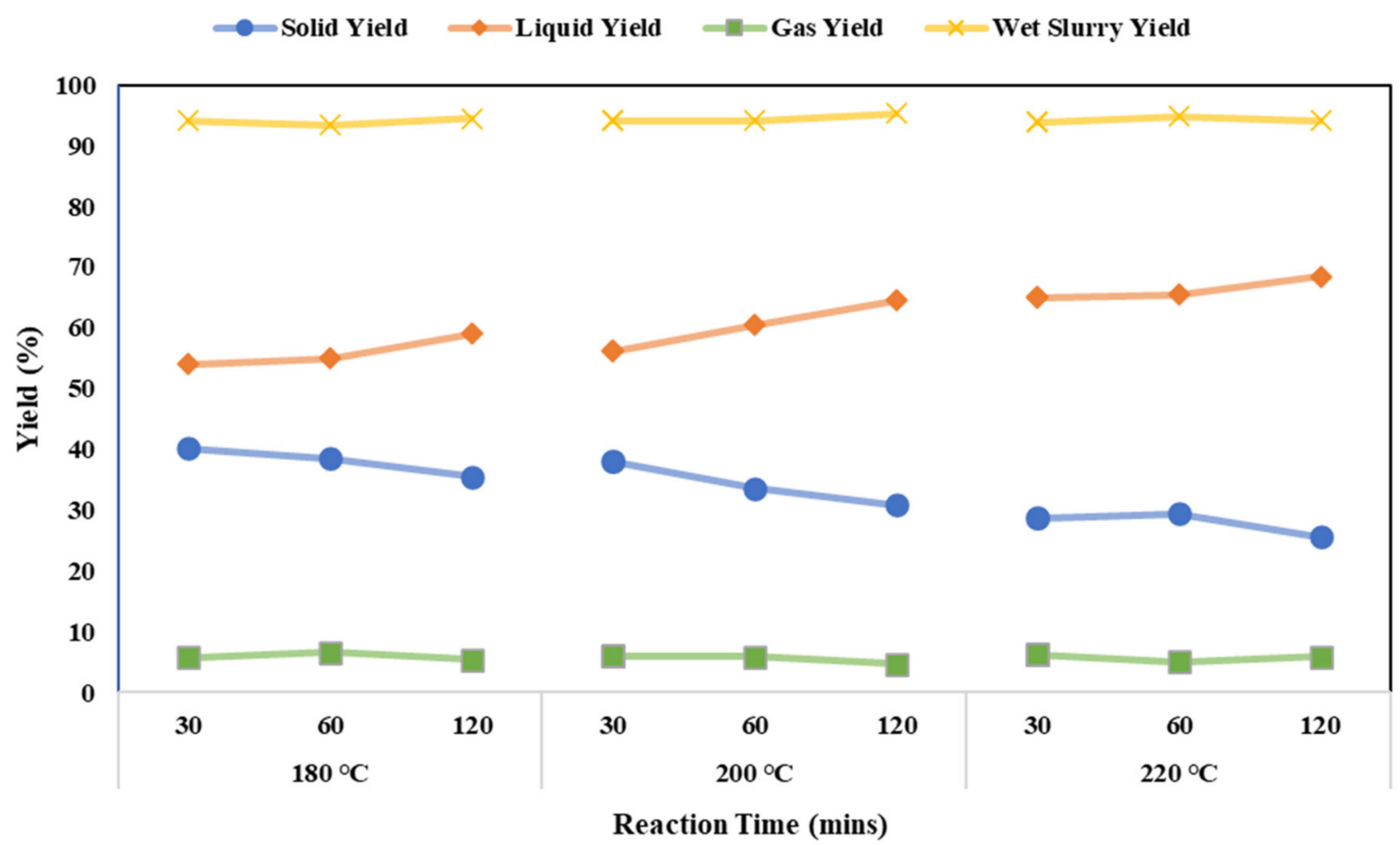

Figure 5. Effect of the reaction/residence time on the product yields in HTC.

Figure 6 shows the effect of the reaction time on the mass yield of the hydrochar. The mass yield of the hydrochar decreased by around $1.5 \%$ at $180{ }^{\circ} \mathrm{C}$ with an increase in the reaction time from $30 \mathrm{~min}$ to $120 \mathrm{~min}$, whereas the mass yield of the seaweed at $200{ }^{\circ} \mathrm{C}$ and $220{ }^{\circ} \mathrm{C}$ reduced by around $6 \%$ when the reaction time was increased from $30 \mathrm{~min}$ to $120 \mathrm{~min}$. Low resistance to mass transfer and increased heat transfer with water in HTC condition results in faster hydrolysis, as a result of which the effect of residence time is minimal on the solid and the mass yield of hydrochar. Hemicellulose, due to its amorphous structure and low degree of polymerization, hydrolyses at a faster rate as compared to cellulose and lignin in the biomass in HTC conditions. Thus, at $200-220^{\circ} \mathrm{C}$, some effects of reaction time were observed. 


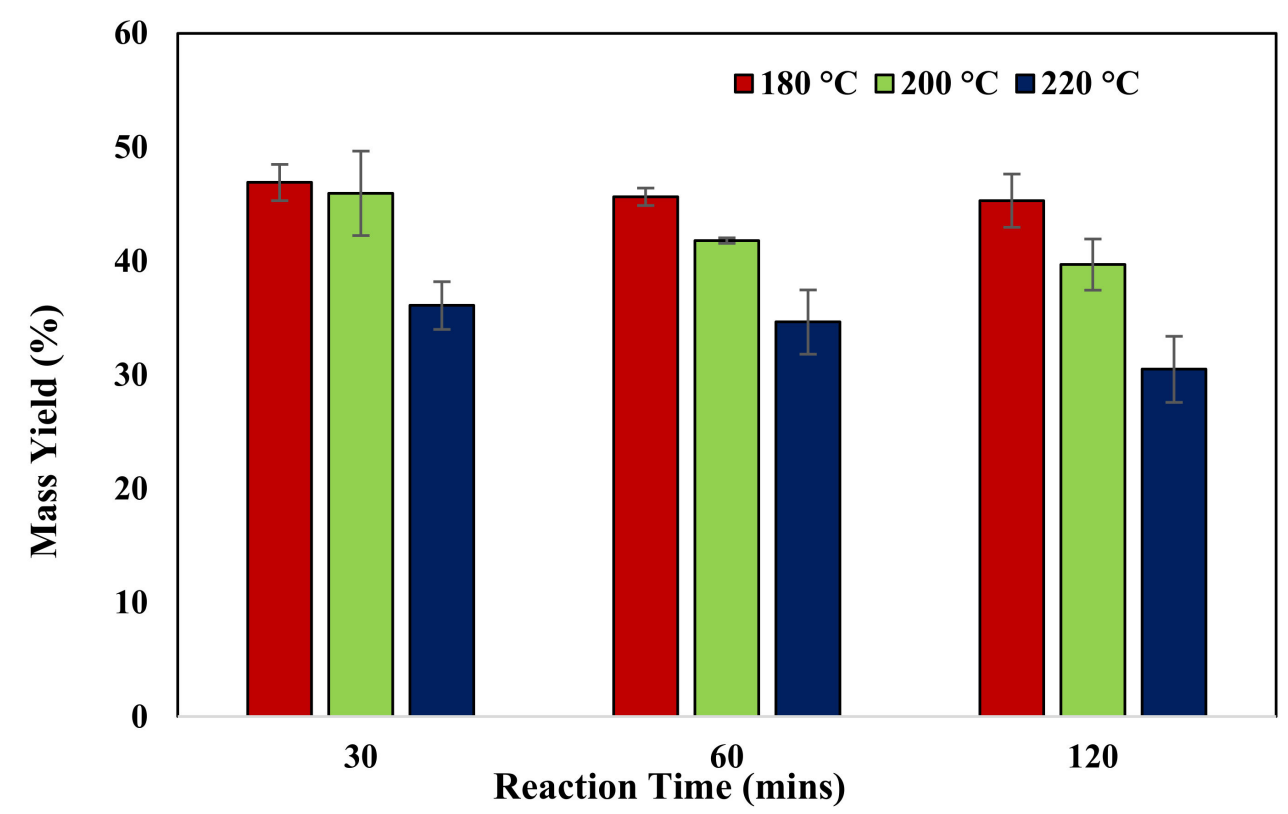

Figure 6. Effect of the reaction temperature on the mass yield of the hydrochar in HTC.

\subsection{Effect of the HTC Process Conditions on HHV and Energy Yield of the Hydrochar}

Table 2 shows the effect of reaction temperature and reaction time on the higher heating value (HHV), lower heating value (LHV), energy densification ratio (EDR), and the energy yield of the hydrochar.

Table 2. The energy analysis of hydrochar.

\begin{tabular}{ccccccc}
\hline $\begin{array}{c}\text { Process } \\
\text { Parameters }\end{array}$ & \multicolumn{3}{c}{ Product Yields } \\
\hline Temperature $\left({ }^{\circ} \mathbf{C}\right)$ & Time (mins) & HHV (MJ/kg) & LHV (MJ/kg) & EDR & Mass Yield (\%) & Energy Yield (\%) \\
\hline 180 & 30 & $13.81 \pm 0.26$ & 12.72 & 1.13 & 46.9 & 53.09 \\
180 & 60 & $15.76 \pm 0.71$ & 15.26 & 1.29 & 45.65 & 58.97 \\
180 & 120 & $16.63 \pm 0.32$ & 16.45 & 1.36 & 45.3 & 61.75 \\
200 & 30 & $16.39 \pm 0.61$ & 14.68 & 1.34 & 45.95 & 61.73 \\
200 & 60 & $17.58 \pm 0.27$ & 16.44 & 1.44 & 41.8 & 60.23 \\
200 & 120 & $18.12 \pm 0.06$ & 17.28 & 1.48 & 39.7 & 58.96 \\
220 & 30 & $17.55 \pm 0.39$ & 15.54 & 1.44 & 36.1 & 53.11 \\
220 & 60 & $18.27 \pm 0.25$ & 17.00 & 1.50 & 34.65 & 53.51 \\
220 & 120 & $18.93 \pm 0.24$ & 17.88 & 1.55 & 30.5 & 49.65 \\
\hline
\end{tabular}

HHV of the raw seaweed: $12.21 \pm 0.17 \mathrm{MJ} / \mathrm{kg}$ and LHV: $11.03 \mathrm{MJ} / \mathrm{kg}$.

The higher heating value (HHV) of the hydrochar samples increased with an increase in the reaction temperature and the reaction time. By increasing the reaction temperature from $180{ }^{\circ} \mathrm{C}$ to $220^{\circ} \mathrm{C}$, the HHV of the hydrochar increased by $27.08 \%$ at the reaction time of $30 \mathrm{~min}$, by $15.92 \%$ at the reaction time of $60 \mathrm{~min}$, and by $13.83 \%$ at the reaction time of $120 \mathrm{~min}$. On the other hand, by increasing the reaction time from $30 \mathrm{~min}$ to $120 \mathrm{~min}$, the $\mathrm{HHV}$ of the hydrochar increased by $20.42 \%$ at $180{ }^{\circ} \mathrm{C}$, by $10.55 \%$ at $200{ }^{\circ} \mathrm{C}$, and by $7.86 \%$ at $220^{\circ} \mathrm{C}$. Owing to decrease in volatile matter caused by the chemical dehydration and decarboxylation reaction, an increase in carbon content resulted in hydrochar with higher heating value [44-46].

The energy densification ratio of hydrochar samples was between 1.13 and 1.55 at the studied reaction conditions. This means that the HTC process resulted in an energy-dense hydrochar. Xu et al. [44] and Brown et al. [41] reported similar results for the HTC of macro-algae. From Table 2, it can be observed that the energy yield of hydrochar increased by around $9 \%$ with the increase in reaction time at $180{ }^{\circ} \mathrm{C}$. Contrary to this, at $200{ }^{\circ} \mathrm{C}$ and 
$220{ }^{\circ} \mathrm{C}$, the energy yield of hydrochar samples decreased by around $3 \%$ by increasing the reaction time. The mass loss at $180^{\circ} \mathrm{C}$ could be attributed to the higher reduction in ash content than the decomposition of the biomass, resulting in hydrochar of higher heating value and higher energy yield with an increase in reaction time.

\subsection{Effect of the HTC Process Conditions on Physicochemical Properties of the Hydrochar}

The results of proximate and ultimate analysis of hydrochar are shown in Table 3.

Table 3. Proximate and ultimate analysis of the raw seaweed and the hydrochar samples.

\begin{tabular}{cccccccccc}
\hline \multirow{2}{*}{ Sample } & Moisture & \multicolumn{2}{c}{ Proximate Analysis (Dry Basis) } & \multicolumn{4}{c}{ Ultimate Analysis } \\
\cline { 2 - 9 } & \% & VM \% & FC \% & Ash \% & C \% & H \% & N \% & S \% & O \% \\
\hline Raw Seaweed & 10.46 & 63.29 & 12.44 & 24.28 & 33.76 & 4.19 & 2.33 & 0.69 & 34.75 \\
$180^{\circ} \mathrm{C}, 30 \mathrm{~min}$ & 2.29 & 61.02 & 17.75 & 21.24 & 43.17 & 4.67 & 2.68 & 0 & 28.24 \\
$180^{\circ} \mathrm{C}, 60 \mathrm{~min}$ & 1.81 & 60.53 & 18.42 & 21.05 & 42.58 & 4.91 & 2.66 & 0.1 & 28.70 \\
$180^{\circ} \mathrm{C}, 120 \mathrm{~min}$ & 1.64 & 57.01 & 21.20 & 21.79 & 42.44 & 4.81 & 2.63 & 0.19 & 28.14 \\
$200^{\circ} \mathrm{C}, 30 \mathrm{~min}$ & 1.61 & 59.10 & 20.39 & 20.51 & 44.44 & 4.7 & 2.69 & 0 & 27.70 \\
$200^{\circ} \mathrm{C}, 60 \mathrm{~min}$ & 1.87 & 58.71 & 20.70 & 20.60 & 44.39 & 4.95 & 2.57 & 0.1 & 27.40 \\
$200^{\circ} \mathrm{C}, 120 \mathrm{~min}$ & 1.93 & 56.16 & 23.70 & 20.14 & 44.39 & 4.27 & 2.63 & 0 & 28.57 \\
$220^{\circ} \mathrm{C}, 30 \mathrm{~min}$ & 1.76 & 58.07 & 21.38 & 20.56 & 43.45 & 4.72 & 2.57 & 0.21 & 28.50 \\
$220^{\circ} \mathrm{C}, 60 \mathrm{~min}$ & 1.63 & 57.70 & 22.11 & 20.19 & 46.86 & 4.89 & 2.8 & 0.13 & 25.13 \\
$220^{\circ} \mathrm{C}, 120 \mathrm{~min}$ & 1.83 & 54.15 & 24.15 & 21.70 & 48.49 & 4.53 & 2.91 & 0.16 & 22.21 \\
\hline
\end{tabular}

A decrease in volatile matter and ash and subsequent increase in fixed carbon in the hydrochar is observed with the increase in reaction temperature and time. Similarly, an increase in carbon content and decrease in oxygen content is observed. These properties of hydrochar make it a suitable fuel for power generation. In order to compare its feasibility to be used as fuel for power generation, the results were plotted in a Van Krevelen diagram (Figure 7). With an increase in HTC reaction temperature and time, the hydrogen to carbon $(\mathrm{H} / \mathrm{C})$ and oxygen to carbon $(\mathrm{O} / \mathrm{C})$ ratio shifted from biomass regions towards peat, which indicates improvement in fuel properties. The hydrochar produced at a reaction temperature of $220^{\circ} \mathrm{C}$ and a reaction time of $120 \mathrm{~min}$ is closer to the range of lignite-a higher-ranking fuel than peat. In addition to a decrease in $\mathrm{H} / \mathrm{C}$ and $\mathrm{O} / \mathrm{C}$ ratio, the ash yield (Figure 8) is reduced in the hydrochar as compared to raw seaweed. The ash yield results show a reduction of more than $60 \%$ in all the hydrochar samples. Furthermore, the ash yield reduced by $10-15 \%$ as the reaction temperature increased from $180{ }^{\circ} \mathrm{C}$ to $220{ }^{\circ} \mathrm{C}$. The highest reduction in ash yield was $73 \%$ as compared to raw seaweed at a reaction temperature of $220^{\circ} \mathrm{C}$ and a reaction time of $120 \mathrm{~min}$. However, the hydrochar still contains around $21 \%$ of ash. This higher ash content in the hydrochar could still limit the use of hydrochar as a fuel for power generation. Alternatively, it could be used for soil remediation applications. The carbon to nitrogen $(\mathrm{C} / \mathrm{N})$ ratio in the hydrochar samples, as shown in Figure 9, increased by 19\% (from 14.49 to 17) compared to the raw seaweed. The increase in $\mathrm{C} / \mathrm{N}$ ratio and presence of nutrients make hydrochar more suitable for soil remediation applications as compared to raw seaweed. 


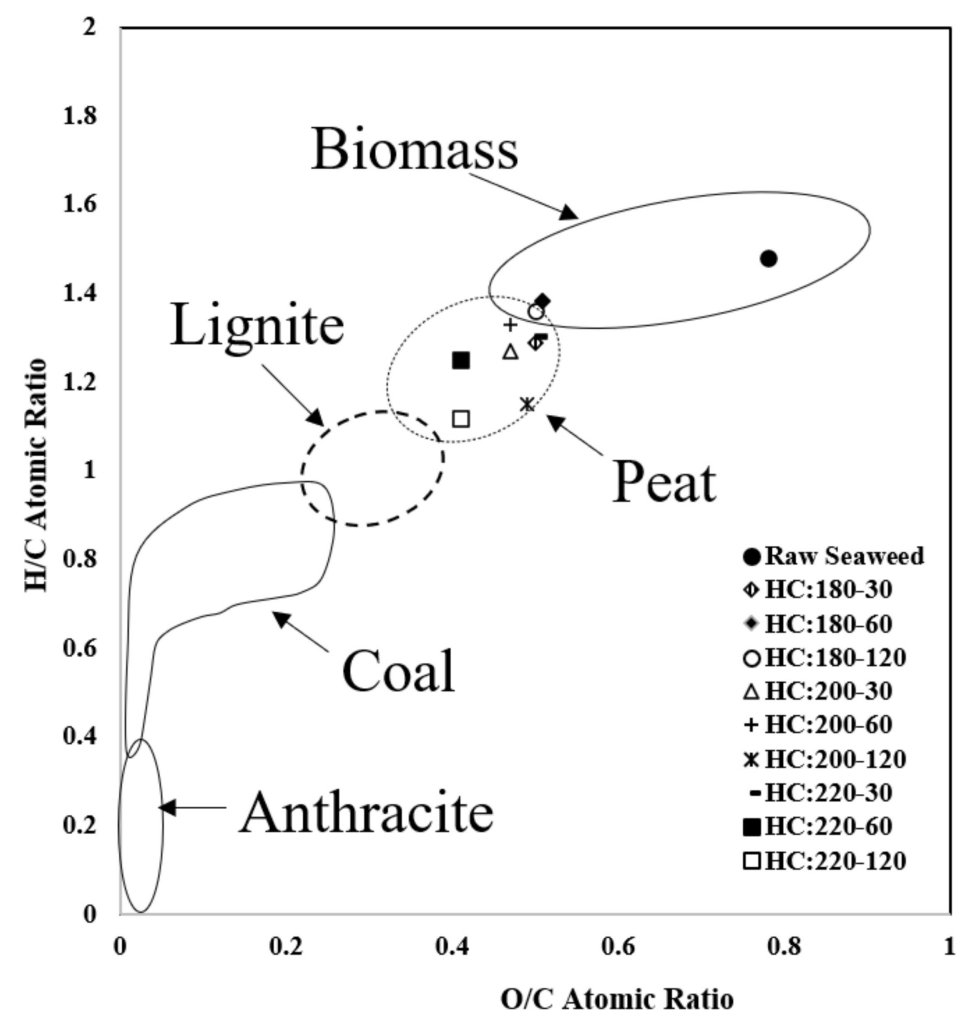

Figure 7. Atomic $\mathrm{H} / \mathrm{C}-\mathrm{O} / \mathrm{C}$ ratios for the hydrochar samples and the raw seaweed.

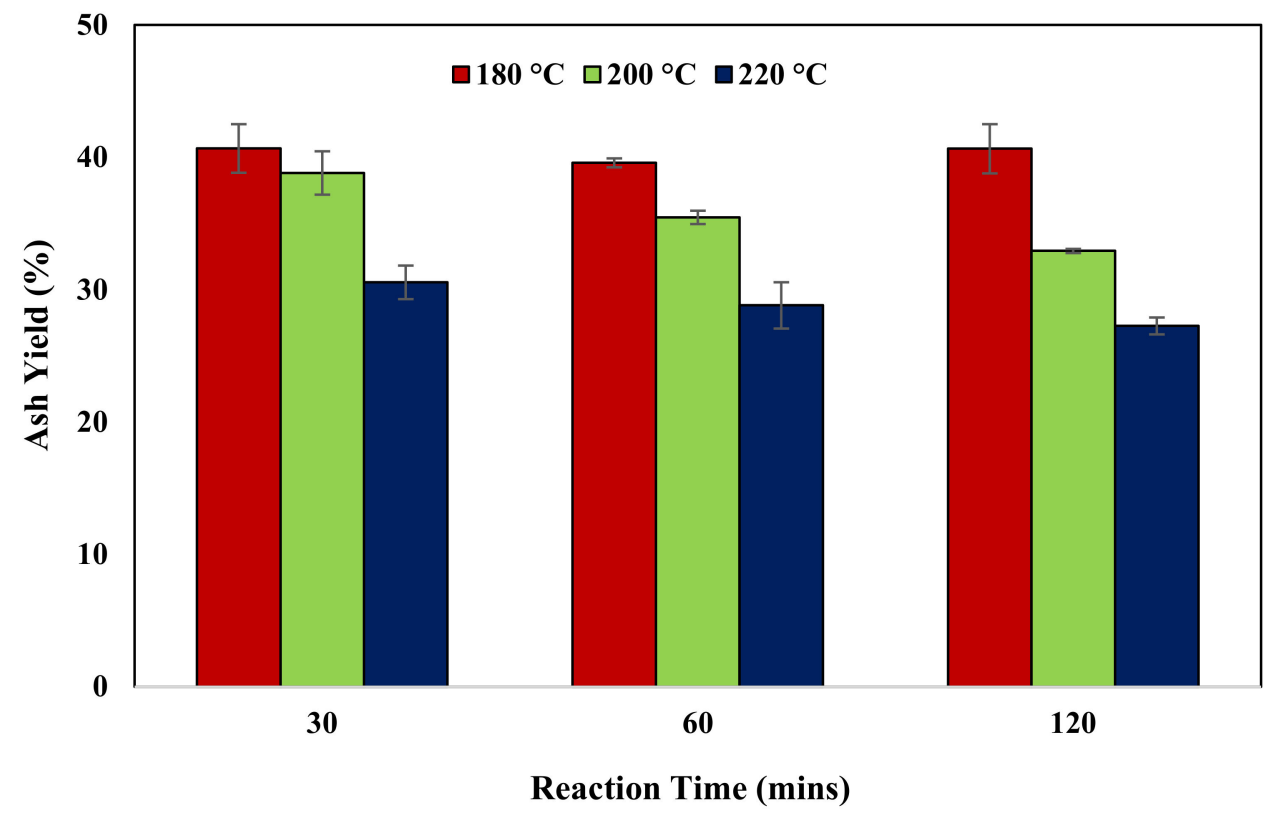

Figure 8. Effect of the process conditions on the ash yield of hydrochar in the HTC. 


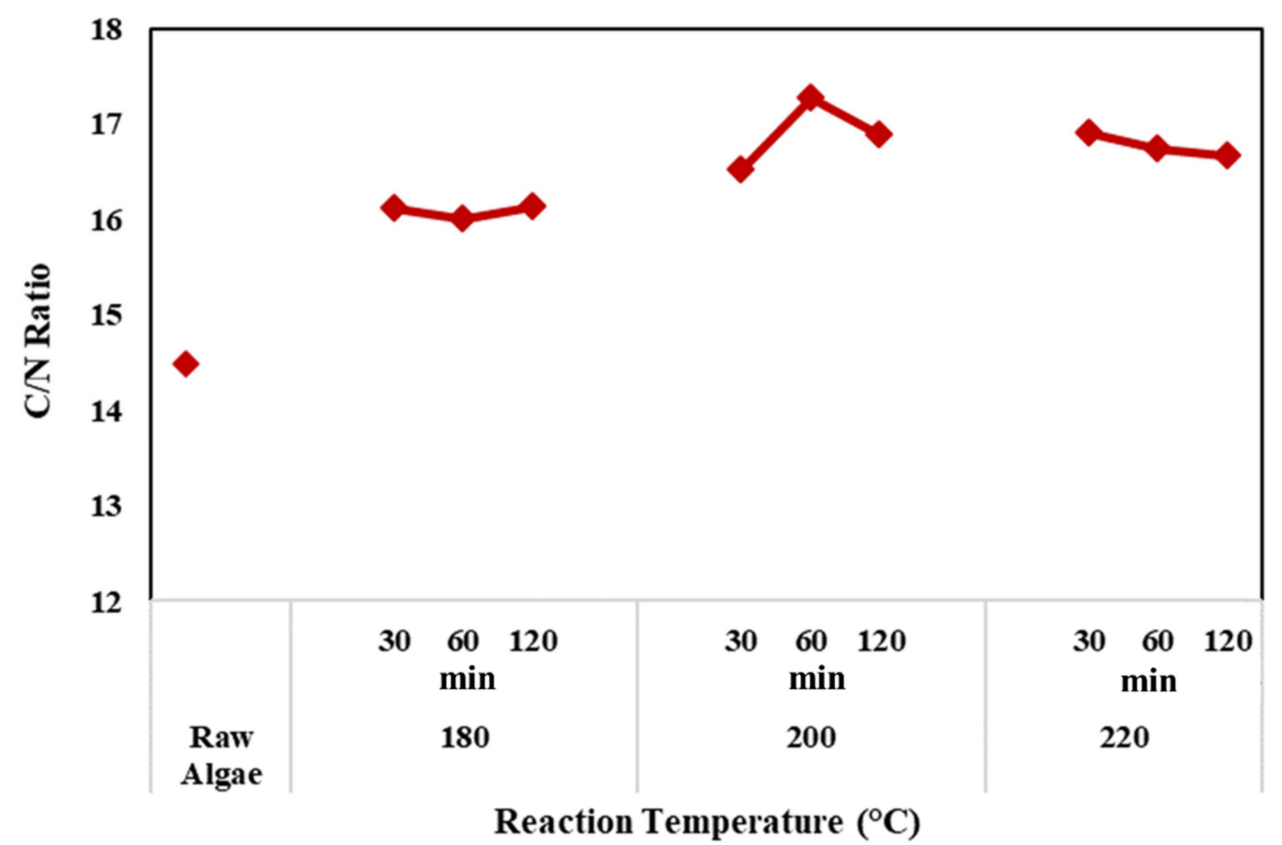

Figure 9. Effect of the process conditions on the $\mathrm{C} / \mathrm{N}$ ratio of hydrochar in the HTC.

\subsection{Effects of the HTC Process Conditions on the Mineral (Inorganic) Composition of the Hydrochar}

Figure 10 shows the mineral content in the raw seaweed and hydrochar obtained under different reaction conditions. The primary minerals, i.e., the inorganic elements present in the raw seaweed, are phosphorus $(\mathrm{P})$, sodium $(\mathrm{Na})$, potassium $(\mathrm{K})$, calcium $(\mathrm{Ca})$, chlorine $(\mathrm{Cl})$, magnesium $(\mathrm{Mg})$, boron $(\mathrm{B})$, manganese $(\mathrm{Mn})$, copper $(\mathrm{Cu})$, zinc $(\mathrm{Zn})$, and sulfur (S). Among these, the content of potassium and calcium is the highest, and the percentage content of copper and zinc is the lowest. The reduction in the percentage of the inorganic yield with the increase in reaction temperature was 31-74\% (Figure 10a), $4-77 \%$ (Figure 10b), and 15-82\% (Figure 10c) at the reaction time of $30 \mathrm{~min}, 60 \mathrm{~min}$, and $120 \mathrm{~min}$, respectively. It is noticeable that the reduction in the inorganic yields of potassium, calcium, magnesium, and boron was at least $50 \%$ for all the hydrochar samples, except for calcium at a temperature of $180{ }^{\circ} \mathrm{C}$ and a reaction time of $120 \mathrm{~min}$. Unlike other minerals, the inorganic yield of phosphorus increased with an increase in the reaction temperature. Hensen et al. [45] also reported similar observations for phosphorus in hydrochar obtained from the HTC of different types of biomass. Cui et al. [46] studied the different wetland biomass wastes and also reported an increase in phosphorus content in hydrochar with increase in reaction temperature. They reported that the water-soluble phosphorus in the wetland plants is immobilized into stable phosphorus during HTC at higher temperatures. Sodium and potassium are mostly present in the form of soluble ions, as a result of which removal is higher. Calcium could be present in the form of calcium pectate or calcium oxalate crystals that show poor water solubility; thus, its removal during the HTC process is limited [45]. Seaweed could also contain a significant amount of chlorine, which can have adverse effects when used as fuel in boilers. Chlorine analysis was not carried out in this work, but it is noteworthy to mention that higher removal of chlorine has been obtained from the HTC of macroalgae [41]. Table 4 shows the absolute amount of inorganics in the ash of raw seaweed and hydrochar. 
$\square$ Raw Seaweed $\square 180 \mathrm{C} \square 200 \mathrm{C} \square 220 \mathrm{C}$

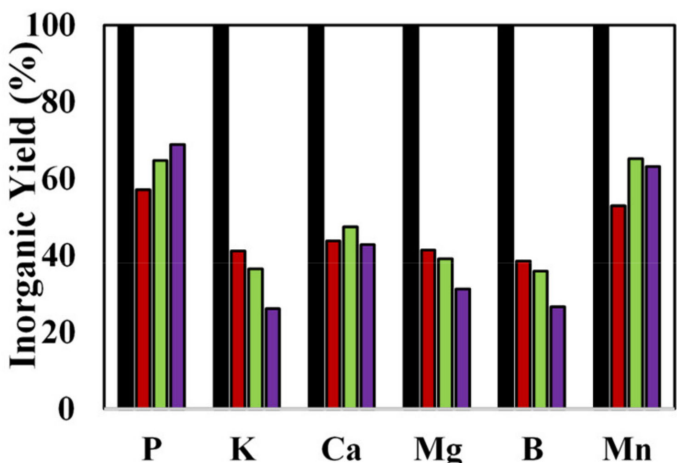

(a) Inorganic Yield of the hydrochar at a reaction time of $30 \mathrm{~min}$ in the HTC
-Raw Seaweed $\square 180 \mathrm{C} \square 200 \mathrm{C} \square 220 \mathrm{C}$

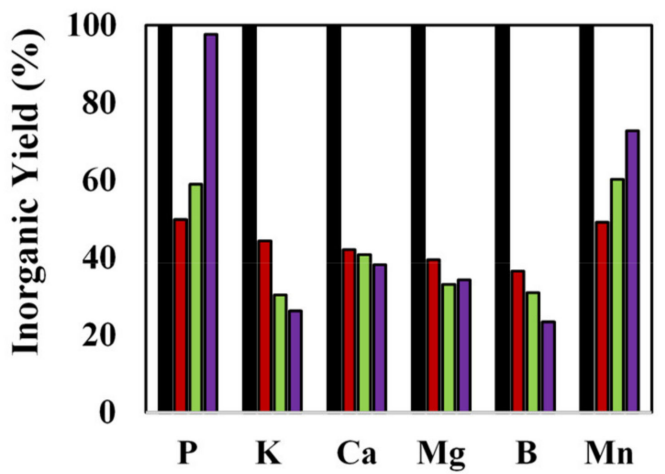

(b) Inorganic Yield of the hydrochar at a reaction time of $60 \mathrm{~min}$ in the HTC

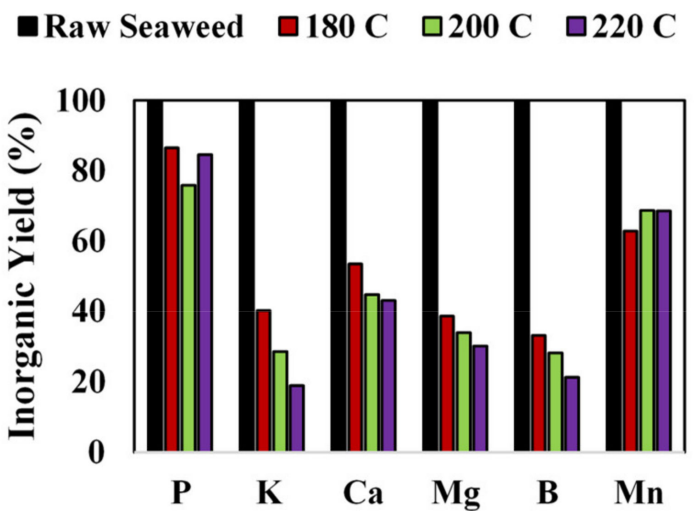

(c) Inorganic Yield of the hydrochar at a reaction time of $120 \mathrm{~min}$ in the HTC

Figure 10. Effect of the process conditions on the inorganic yield of the hydrochar in HTC.

Table 4. The concentration of inorganics in the ash of raw seaweed and hydrochar.

\begin{tabular}{lcccccccc}
\hline \multicolumn{1}{c}{ Sample } & $\mathbf{P ~ ( \% )}$ & K (\%) & Ca (\%) & Mg (\%) & Cu (\%) & Zn (\%) & B (\%) & Mn (\%) \\
\hline Raw Seaweed & 0.22 & 1.31 & 1.51 & 0.81 & 0.0002 & 0.0008 & 0.1508 & 0.1108 \\
$180-30$ & 0.27 & 1.16 & 1.42 & 0.72 & 0.0019 & 0.0016 & 0.1251 & 0.1262 \\
$180-60$ & 0.24 & 1.27 & 1.39 & 0.7 & 0.0013 & 0.0014 & 0.1205 & 0.1192 \\
$180-120$ & 0.42 & 1.16 & 1.78 & 0.69 & 0.0013 & 0.0014 & 0.1099 & 0.1534 \\
$200-30$ & 0.31 & 1.04 & 1.56 & 0.69 & 0.0009 & 0.0018 & 0.1179 & 0.1573 \\
$200-60$ & 0.31 & 0.95 & 1.47 & 0.64 & 0.0008 & 0.0016 & 0.1114 & 0.1595 \\
$200-120$ & 0.42 & 0.94 & 1.7 & 0.69 & 0.001 & 0.002 & 0.1069 & 0.1917 \\
$220-30$ & 0.42 & 0.95 & 1.79 & 0.7 & 0.001 & 0.0019 & 0.1113 & 0.194 \\
$220-60$ & 0.62 & 0.99 & 1.66 & 0.8 & 0.0013 & 0.0022 & 0.1018 & 0.2326 \\
$220-120$ & 0.61 & 0.81 & 2.13 & 0.8 & 0.0015 & 0.0023 & 0.1048 & 0.2491 \\
\hline
\end{tabular}

\subsection{Effect of the HTC Process Conditions on the Characteristics of the Processed Water}

Figure 11a shows the effect of the reaction temperature on the inorganic element yield in the processed water for a reaction time of $120 \mathrm{~min}$. As expected, the effect of reaction temperature on the inorganic yield in process water follows the opposite trend to that of 
inorganic yield in hydrochar. Figure $11 \mathrm{~b}$ shows the effect of the reaction temperature and the reaction time on the $\mathrm{pH}$ value of the processed water in the HTC process. Irrespective of the reaction severity, i.e., the process conditions, the $\mathrm{pH}$ of the processed water was acidic in nature. The acidic $\mathrm{pH}$ can be attributed to the formation of acidic compounds due to degradation of the biomass polymers and formation of organic acids, predominantly acetic acid. Moreover, when deionized water is exposed to the atmosphere, its $\mathrm{pH}$ shifts to the acidic side of the $\mathrm{pH}$ scale because it quickly reacts with the carbon dioxide $\left(\mathrm{CO}_{2}\right)$ in the air to form carbonic acid. However, due to the marginal difference among the $\mathrm{pH}$ levels of different processed water samples, it can be argued that a change in either the reaction temperature or the reaction time has a lesser effect on the change in the $\mathrm{pH}$ of the processed water in the HTC conditions studied in this research.

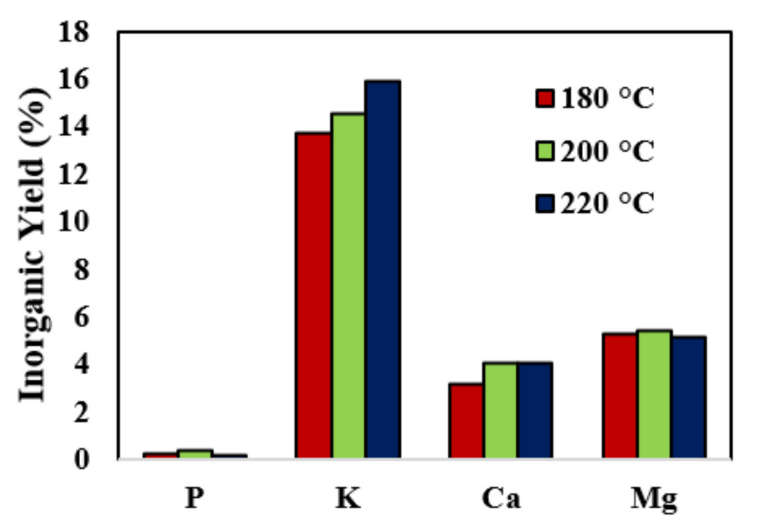

(a) Effect of the reaction temperature on the inorganic elemental composition of the processed water in HTC

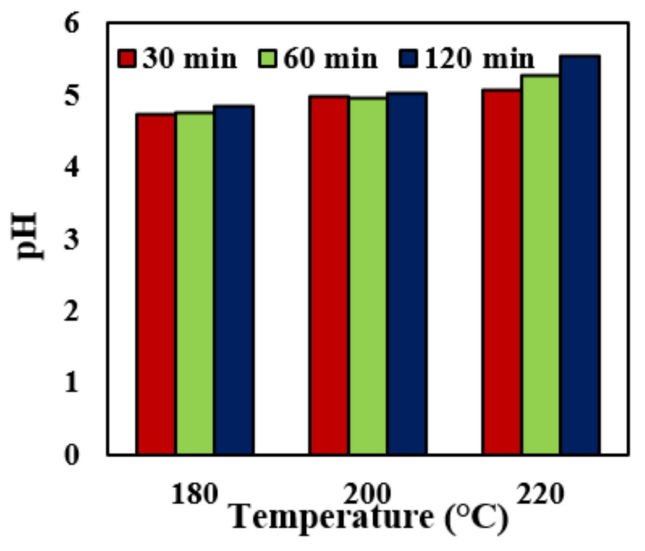

(b) Effect of the process conditions on the $\mathrm{pH}$ of the processed water in HTC

Figure 11. Effect of the reaction temperature on the inorganic elemental composition and $\mathrm{pH}$ of the processed water.

\section{Conclusions}

Hydrothermal carbonization of seaweed was carried out in the temperature range of $180-220^{\circ} \mathrm{C}$ and at a reaction time $30-120 \mathrm{~min}$. With the increase in reaction temperature and time, the mass yield of hydrochar decreased from $46.9 \%$ to $30.5 \%$. The maximum heating value of $18.93 \mathrm{MJ} / \mathrm{kg}$ was obtained for the hydrochar produced at a reaction temperature of $220^{\circ} \mathrm{C}$ and a reaction time of $120 \mathrm{~min}$. The same reaction conditions resulted in hydrochar with higher carbon content. Atomic ratios $(\mathrm{H} / \mathrm{C}$ and $\mathrm{O} / \mathrm{C})$ for hydrochar decreased with increasing reaction conditions. The hydrochar, which is produced at the reaction temperature of $220^{\circ} \mathrm{C}$ and reaction time of $120 \mathrm{~min}$, is very near to the range of lignite. The volatile matter was found to be lowest $(54.15 \%)$ for the hydrochar produced at a reaction temperature of $220^{\circ} \mathrm{C}$ and reaction time of $120 \mathrm{~min}$. The hydrochar showed a significant reduction in the ash yield (at least 60\%) as compared to raw seaweed. The highest reduction in the ash yield $(\sim 73 \%)$ was found in the hydrochar produced at a reaction temperature of $220^{\circ} \mathrm{C}$ and a reaction time of $120 \mathrm{~min}$. The lowest reduction in the ash yield $(\sim 60 \%)$ was found in the hydrochar produced at a reaction temperature of $220^{\circ} \mathrm{C}$ and $180^{\circ} \mathrm{C}$ at a reaction time of $30 \mathrm{~min}$. Therefore, fouling, slagging, and corrosion-related challenges, related to the combustion of high ash biomass in a boiler, may be mitigated by replacing biomass with hydrochar produced through the HTC of the biomass. Moreover, the HTC process is carried out in an aqueous environment, which allows the efficient and economical utilization of wet biomass, thus substantially increasing the process flexibility regarding suitable biomass. However, phosphorus during the HTC process is retained in the hydrochar, along with potassium. The presence of phosphorus and potassium could 
lead to fouling and corrosion issues in boilers, which could limit the use of hydrochar as a fuel in a boiler. On the other hand, the higher $\mathrm{C} / \mathrm{N}$ ratio in hydrochar could provide better soil remediation measures. However, it is recommended in future studies to validate its effectiveness through field studies. This work demonstrated the potential of HTC of seaweed found in PEI as a technique to manage the problem and recover value from it. Future work shall focus on studying the combustion properties of hydrochar and the potential applications of processed water.

Author Contributions: Conceptualization, B.A. and P.B.; methodology, N.P., B.A., and P.B.; formal analysis, N.P. and B.A.; writing—original draft preparation, N.P..; writing-review and editing, B.A.; supervision, B.A. and P.B.; funding acquisition, B.A. and P.B. All authors have read and agreed to the published version of the manuscript.

Funding: This research was funded by Natural Science and Engineering Research Council Discovery Grant program, grant number RGPIN-2016-05728.

Institutional Review Board Statement: Not applicable.

Informed Consent Statement: Not applicable.

Data Availability Statement: Data is contained within the article.

Acknowledgments: Authors would like to thank Ankita Shrestha, Charles Terrio, and Jesse Cameroon for their sincere support of the research activities associated with this article.

Conflicts of Interest: The authors declare no conflict of interest.

\section{References}

1. Wang, T.; Zhai, Y.; Zhu, Y.; Li, C.; Zeng, G. A review of the hydrothermal carbonization of biomass waste for hydrochar formation: Process conditions, fundamentals, and physicochemical properties. Renew. Sustain. Energy Rev. 2018, 90, 223-247. [CrossRef]

2. Vassilev, S.V.; Baxter, D.; Andersen, L.K.; Vassileva, C.G. An overview of the chemical composition of biomass. Fuel 2010, 89, 913-933. [CrossRef]

3. Basu, P. Biomass Gasification, Pyrolysis and Torrefaction: Practical Design and Theory; Academic Press: Cambridge, MA, USA, 2018.

4. Naik, S.N.; Goud, V.V.; Rout, P.K.; Dalai, A.K. Production of first and second generation biofuels: A comprehensive review. Renew. Sustain. Energy Rev. 2010, 14, 578-597. [CrossRef]

5. Ramirez, C.H.V. Biogas Production from Seaweed Biomass: A Biorefinery Approach. Ph.D. Thesis, Institute of Technology, Sligo, Ireland, 2017.

6. Nigam, P.S.; Singh, A. Production of liquid biofuels from renewable resources. Prog. Energy Combust. Sci. 2011, 37, 52-68. [CrossRef]

7. Wei, N.; Quarterman, J.; Jin, Y.-S. Marine macroalgae: An untapped resource for producing fuels and chemicals. Trends Biotechnol. 2013, 31, 70-77. [CrossRef]

8. Khan, N.; Mohan, S.; Dinesha, P. Regimes of hydrochar yield from hydrothermal degradation of various lignocellulosic biomass: A review. J. Clean. Prod. 2021, 288, 125629. [CrossRef]

9. Shen, Y. A review on hydrothermal carbonization of biomass and plastic wastes to energy products. Biomass Bioenergy 2020, 134, 105479. [CrossRef]

10. Sharma, R.; Jasrotia, K.; Singh, N.; Ghosh, P.; Srivastava, S.; Sharma, N.R.; Singh, J.; Kanwar, R.; Kumar, A. A Comprehensive Review on Hydrothermal Carbonization of Biomass and its Applications. Chem. Afr. 2019, 3, 1-19. [CrossRef]

11. Heidari, M.; Dutta, A.; Acharya, B.; Mahmud, S. A review of the current knowledge and challenges of hydrothermal carbonization for biomass conversion. J. Energy Inst. 2019, 92, 1779-1799. [CrossRef]

12. Roman, S.; Libra, J.; Berge, N.; Sabio, E.; Ro, K.; Li, L.; Ledesma, B.; Alvarez, A.; Bae, S. Hydrothermal Carboniza-tion: Modeling, Final Properties Design, and Applications: A Review. Energies 2018, 11, 216. [CrossRef]

13. Reza, M.T.; Lynam, J.G.; Uddin, M.H.; Coronella, C.J. Hydrothermal carbonization: Fate of inorganics. Biomass Bioenergy 2013, 49, 86-94. [CrossRef]

14. Reza, M.T.; Yan, W.; Uddin, M.H.; Lynam, J.G.; Hoekman, S.K.; Coronella, C.J.; Vásquez, V.R. Reaction kinetics of hydrothermal carbonization of loblolly pine. Bioresour. Technol. 2013, 139, 161-169. [CrossRef] [PubMed]

15. Pavlovič, I.; Knez, Ž.; Škerget, M. Hydrothermal Reactions of Agricultural and Food Processing Wastes in Sub- and Supercritical Water: A Review of Fundamentals, Mechanisms, and State of Research. J. Agric. Food Chem. 2013, 61, 8003-8025. [CrossRef]

16. Funke, A.; Ziegler, F. Hydrothermal carbonization of biomass: A summary and discussion of chemical mechanisms for process engineering. Biofuels Bioprod. Biorefin. 2010, 4, 160-177. [CrossRef]

17. Patel, B.; Guo, M.; Izadpanah, A.; Shah, N.D.; Hellgardt, K. A review on hydrothermal pre-treatment technologies and environmental profiles of algal biomass processing. Bioresour. Technol. 2016, 199, 288-299. [CrossRef] [PubMed] 
18. Kambo, H.S.; Dutta, A. A comparative review of biochar and hydrochar in terms of production, physico-chemical properties and applications. Renew. Sustain. Energy Rev. 2015, 45, 359-378. [CrossRef]

19. Li, H.; Wang, S.; Yuan, X.; Xi, Y.; Huang, Z.; Tan, M.; Li, C. The effects of temperature and color value on hydrochars' properties in hydrothermal carbonization. Bioresour. Technol. 2018, 249, 574-581. [CrossRef] [PubMed]

20. Nizamuddin, S.; Baloch, H.A.; Griffin, G.J.; Mubarak, N.M.; Bhutto, A.W.; Abro, R.; Mazari, S.A.; Ali, B.S. An over-view of the effect of process parameters on hydrothermal carbonization of biomass. Renew. Sustain. Energy Rev. 2017, 73, 1289-1299. [CrossRef]

21. Libra, J.A.; Ro, K.S.; Kammann, C.; Funke, A.; Berge, N.D.; Neubauer, Y.; Titirici, M.-M.; Fühner, C.; Bens, O.; Kern, J.; et al Hydrothermal carbonization of biomass residuals: A comparative review of the chemistry, processes and applications of wet and dry pyrolysis. Biofuels 2011, 2, 71-106. [CrossRef]

22. Fang, J.; Zhan, L.; Ok, Y.S.; Gao, B. Minireview of potential applications of hydrochar derived from hydrothermal carbonization of biomass. J. Ind. Eng. Chem. 2018, 57, 15-21. [CrossRef]

23. Titirici, M.-M.; White, R.J.; Falco, C.; Sevilla, M. Black perspectives for a green future: Hydrothermal carbons for environment protection and energy storage. Energy Environ. Sci. 2012, 5, 6796-6822. [CrossRef]

24. Mäkelä, M.; Benavente, V.; Fullana, A. Hydrothermal carbonization of lignocellulosic biomass: Effect of process conditions on hydrochar properties. Appl. Energy 2015, 155, 576-584. [CrossRef]

25. Smith, A.M.; Singh, S.; Ross, A.B. Fate of inorganic material during hydrothermal carbonisation of biomass: Influence of feedstock on combustion behaviour of hydrochar. Fuel 2016, 169, 135-145. [CrossRef]

26. Bhatt, D.; Shrestha, A.; Dahal, R.K.; Acharya, B.; Basu, P.; MacEwen, R. Hydrothermal Carbonization of Biosolids from Waste Water Treatment Plant. Energies 2018, 11, 2286. [CrossRef]

27. Danso-Boateng, E.; Holdich, R.G.; Wheatley, A.D.; Martin, S.J.; Shama, G. Hydrothermal Carbonisation of Primary Sewage Sludge and Synthetic 1 Faeces: Effect of Reaction Temperature and Time on Filterability. Environ. Prog. Sustain. Energy 2015, 34, 1279-1290. [CrossRef]

28. AVA- $-\mathrm{CO}_{2}$ Introduces the First Industrial-Size Hydrothermal Carbonization (HTC) Plant in the World. Available online: https: / www.businesswire.com/news/home/20101026006679/en/AVA-CO2-Introduces-Industrial-Size-HydrothermalCarbonisation-HTC-Plant (accessed on 5 April 2018).

29. The Ingelia Patented HTC Plant. Available online: https://ingelia.com/index.php/modelo-negocio/carbonizacion-de-biomasa/ ?lang=en (accessed on 10 May 2019).

30. Shrestha, A.; Acharya, B.; Farooque, A.A. Study of hydrochar and process water from hydrothermal carbonization of sea lettuce. Renew. Energy 2021, 163, 589-598. [CrossRef]

31. Shrestha, A. Sea Lettuce to Biocarbon and Biogas with Recovery of Nutrients. Master's Thesis, University of Prince Edward Island, Charlottetown, PE, Canada, 2019.

32. Singh, R.; Bhasker, T.; Balagurumurthy, B. Hydrothermal Upgradation of Algae into Value-Added Hydrocarbons. In Biofuels from Algae; Pandey, A., Lee, D.-J., Chisti, Y., Soccol, C., Eds.; Elsevier: Burlington, MA, USA, 2014; Chapter 11, ISBN 978-0-444-59558-4.

33. Suganya, T.; Varman, M.; Masjuki, H.H.; Renganathan, S. Macroalgae and microalgae as potential source for commercial application along with biofuels production: A biorefinery approach. Renew. Sustain. Energy Rev. 2016, 55, 909-941. [CrossRef]

34. Jard, G.; Marfaing, H.; Carrere, H.; Delgenes, J.P.; Steyer, J.P.; Dumas, C. French Brittany macroalgae screening: Composition and methane potential for possible alternative sources of energy and products. Bioresour. Technol. 2013, 144, 492-498. [CrossRef]

35. More Seaweed than Ever before Is Washing Up along Green's Shore. Available online: https://www.journalpioneer.com/news / local/seaweed-accumulation-growing-55871/ (accessed on 29 September 2017).

36. PEI Department of Environment, Labour and Justice and The PEI department of Fisheries, Aquaculture and Rural Development (2012) Sea Lettuce Harvest Pilot Project Report. Available online: http://www.gov.pe.ca/photos/original/elj_sealett_rpt.pdf (accessed on 10 January 2018).

37. CBC News. Seaweed Fertilizer Creates Big Stink. Available online: https://www.cbc.ca/news/canada/prince-edward-island/ seaweed-fertilizer-creates-big-stink-1.2101106 (accessed on 11 May 2018).

38. CBC News. Summerside Seeks Seaweed Smell Solution. Available online: https://www.cbc.ca/news/canada/prince-edwardisland/summerside-seeks-seaweed-smell-solution-1.2807075 (accessed on 11 May 2018).

39. Vlachokostas, C.; Achillas, C.; Agnantiaris, I.; Michailidou, A.V.; Pallas, C.; Feleki, E.; Moussiopoulos, N. Decision Support System to Implement Units of Alternative Biowaste Treatment for Producing Bioenergy and Boosting Local Bioeconomy. Energies 2020, 13, 2306. [CrossRef]

40. Tumuluru, J.S.; Sokhansanj, S.; Hess, J.R.; Wright, C.T.; Boardman, R.D. REVIEW: A review on biomass torrefaction process and product properties for energy applications. Ind. Biotechnol. 2011, 7, 384-401. [CrossRef]

41. Brown, A.E.; Finnerty, G.L.; Camargo-Valero, M.A.; Ross, A.B. Valorization of macroalgae via the integration of hydrothermal carbonization and anaerobic digestion. Bioresour. Technol. 2020, 312, 123539. [CrossRef]

42. Bobleter, O. Hydrothermal degradation of polymers derived from plants. Prog. Polym. Sci. 1994, 19, 797-841. [CrossRef]

43. Partridge, A.; Sermyagina, E.; Vakkilainen, E. Impact of Pretreatment on Hydrothermally Carbonized Spruce. Energies 2020, 13, 2984. [CrossRef] 
44. Xu, Q.; Qian, Q.; Quek, A.; Ai, N.; Zeng, G.; Wang, J. Hydrothermal Carbonization of Macroalgae and the Effects of Experimental Parameters on the Properties of Hydrochars. ACS Sustain. Chem. Eng. 2013, 1, 1092-1101. [CrossRef]

45. Hansen, L.J.; Fendt, S.; Spliethoff, H. Impact of hydrothermal carbonization on combustion properties of residual biomass. Biomass Convers. Biorefin. 2020, 1-12. [CrossRef]

46. Cui, X.; Lu, M.; Khan, M.B.; Lai, C.; Yang, X.; He, Z.; Chen, G.; Yan, B. Hydrothermal carbonization of different wetland biomass wastes: Phosphorus reclamation and hydrochar production. Waste Manag. 2020, 102, 106-113. [CrossRef] [PubMed] 